includes the announcement that Prof. Fermi has produced a new element, of atomic number 93 . The new element was found when uranium, atomic number 92, was bombarded with neutrons; it is radioactive, with a half-period of about 13 minutes. This announcement would appear to be a sequel to the experiments reported by Prof. Fermi in Nature of May 19, p. 757, when he described the effects of bombarding various elements with a powerful stream of neutrons. Uranium was not among the elements mentioned by Prof. Fermi in his communication, but it would seem that he has now succeeded in obtaining an effect from it.

\section{Science and Psychical Research}

EARLY this year (January 6, p. 18) we referred to the proposed formation of a body to be called "The International Institute for Psychical Research", and expressed the hope that the men of science who had allowed their names to appear on the circular announcing the new organisation would see that whatever invesstigations were undertaken were in accord with what science demands of such inquiries. Apparently it has been difficult to secure these essential conditions, for Prof. D. F. Fraser-Harris, who was announced as the research officer of the Institute, informs us that he has resigned that position. When he invited a number of scientific friends to serve on the Committee of the Institute, he was under the impression that a laboratory was to be provided, but he now finds this is not so, and that there is a lack of appreciation of what scientific investigation signifies. It may be recalled that Prof. Elliot Smith, who was advertised a short time ago as president of the Institute, resigned a few weeks ago on account of ill-health. We understand that most of the chief men of science whose names were advertised in the list of members of the Consultative Committee of the Institute have also resigned. In connexion with the subject of psychical research, Prof. Fraser-Harris, referring to the article "From a Correspondent" in Nature of May 19, p. 747, writes :- "There is one circumstance not mentioned by the author of the account of the experiments of MM. Osty (1932) on 'the unknown powers' produced by Rudi Schneider. It is the fact that, between the medium and the sitters on one hand and the recording apparatus on the other, there was inter. posed a sheet of muslin stretched on a wooden frame. Clearly, the medium on one side of this partition, even with all his limbs free and surrounded by any number of accomplices, could not have played any tricks with the apparatus on the far side of the partition. (A photograph of this screen is on p. 54 of Revre Metapsychique. 1932. No. I.)"

\section{Tornado at Concepcion}

A BRIEF summary of damage and loss of life caused by a tornado on May 27 in the Chilean town of Concepcion, the chief port of entry to southern Chile, appeared in some evening papers on May 28, and in the Times of May 29. The storm was described as a "cyclone", but the note in the Times stated that the damage occurred in a strip $65 \mathrm{ft}$. wide, and if that statement is correct, there can be no doubt that this was a tornado of the American pattern, and a vigorous example at that, seeing that trees were uprooted and buildings were wrecked as the storm swept across the town, moving apparently from east to west. One account stated that a house was lifted off the ground and carried along for a distance of nearly 55 yards. The incident is of especial scientific interest ; if the 'dust devils' of desert regions and the maritime or lacustrine 'waterspouts' are included under the term 'tornado', there appears to be hardly any part of the world where this small intense rotary storm may not occasionally occur; they are not uncommon in the Mediterranean, and Concepcion lies in the corresponding southern latitude and has the same type of climate with maximum rainfall in the winter half of the year. It is then that the westerly winds invade a region that fringes the trade wind belt during the summer. The date of this particular storm corresponds with late November in the Mediterranean, and in both regions the late autumn is in general about the middle of the wettest quarter of the year, when the tornado might be expected to occur most often in coastal regions, even though the American tornado is more a phenomenon of the late spring and summer.

\section{Trevithick Centenary Commemoration}

Aт a meeting of the general committee of the Trevithick Centenary Commemoration, held on May 31 at the Institution of Civil Engineers and presided over by Sir Murdoch Macdonald, the report of the Executive Committee appointed in October 1932 to make arrangements for the commemoration was presented by Mr. H. W. Dickinson, honorary secretary, and passed. The report showed that about $£ 500$ had been subscribed, and that the com. mittee had been able to carry through the plans laid down. Memorial services were held in Westminster Abbey and Dartford Parish Church, a memorial lecture was delivered by Prof. C. E. Inglis, and memorial tablets have been erected at Merthyr Tydfil to mark the site of Trevithick's experiment of 1804, and at University College, London, to mark the experiment with the locomotive Catch-me-who-can in 1808. A sum of money had also been allocated to assist in the erection of a tablet at Trevithick's birthplace. The work of the committee had been greatly assisted by the hospitality of the Institution of Civil Engineers and by the generosity of Messrs. Babcock and Wilcox, Ltd., who had defrayed the cost of the publication of the memorial volume on Trevithick by Messrs. Dickinson and Titley. An interesting outcome of the celebration was that it had led the Institution of Civil Engineers to appoint a committee to make an annual visitation to Westminster Abbey to inspeot the various memorials to engineers there.

\section{Expedition to the Canadian Arctic}

AN expedition, organised by the Oxford University Exploration Club with the full support of the Royal Geographical Society and the Canadian Government, is sailing shortly for Ellesmere Land in the Canadian 
Arctic, under the leadership of Dr. Noel Humphreys. The plans of the Expedition are to leave London in July in a sealer chartered from Norway and to winter in Ellesmere Land, next spring being devoted to an exploration of Northern Ellesmere Land. The interior is unexplored and a geological survey of this country will be the chief scientific work undertaken. The Expedition is financed partly by its members and partly by scientific societies and individual sub. scribers. The greater part of the food supply has been obtained free owing to the generosity of a number of firms. The Expedition will consist of five or six members, but a geologist is still urgently required. Besides being physically fit and prepared to be away from England for a year, he should have had some field experience. Communications referring to the Expedition should be addressed to Mr. E. A. A. Shackleton, Oxford University Ellesmere Land Expedition, 1934, Royal Geographical Society, London, S.W.7.

\section{Archæological Exploration in Alaska}

Dr. Aueš Hrduička, accompanied by a number of volunteer students, left Washington on May 11 for a further season's work on Kodiak Island, Alaska. Several seasons have already been devoted by Smithsonian expeditions, of which Dr. Hrdlička has been in charge, to the examination of sites on this island. The results have shown that it was at one time thickly populated and was in all probability a stepping stone in the peopling of America by migrants from Asia. The earliest inhabitants, whose skeletal remains have been found at the bottom of the accumulated debris, represent the earliest remains of man which have been found in the far north. They are not, however, ancient in the geological sense. In type they approach the physical characters of the Indians of California and the west coast. The earliest immigrants introduced a high order of stone culture, and many of the objects found with them are unique. They were succeeded by the Aleut, who were the inhabitants at the time of the coming of the Russians. A remarkable feature in the culture of the older population is that it is not identical throughout. A marked change takes place in the course of their period of occupation. In the coming season, work will be confined to one large village, already partially explored. The site will be subjected to intensive study in the hope of obtaining a decisive answer to some, at least, of the problems which have been raised in the investigations of previous years.

\section{International Eugenics Conference}

THE biennial conference of the International Federation of Eugenic Organisations will take place at Zurich on July 18-21 under the presidency of Prof. Ernst Rüdin of Munich. A programme has been arranged providing for the discussion of subjects of immediate interest in which eminent specialists have been invited to take part. Addresses will be delivered by, among others, Prof. Rüdin on "Racial Psychiatry - a Scheme for Topographical Research in Europe", Dr. Mjoer on "Measurement of Psycho- logical Faculty as shown in Musical Ability", and Prof. Von Verschuer on "Researches in Twins". Dr. Rüdin will also explain the provisions of the recent German eugenics law; and it is hoped that one of the public health officers of the Reich will give an address on the questionnaire now used in Germany for assessing intelligence grade. Among the subjects down for discussion are the assessment of feeble-mindedness-to be held in a joint session of the Committee for Racial Psychiatry and Section $\mathrm{B}$ of the International Committee for the Standardisation of Human Measurement mental measurement and its relation to diagnosis of temperamental type, aspects of the problems of differences between, and inheritance in, monozygotic and dizygotic twins, and the best methods of conducting a central clear. ing house for human heredity, this last-named including the questions of the establishment of national bureaux, and the protection of authors whose material is published. The work of the Standardisation Committee in Anthropometry will be continued at the International Congress of Anthropological Sciences to be held in London at the end of July.

\section{Prof. Erwin Baur}

HeFT 17-18 of Die Naturwissenschaften, which appeared on April 27, is devoted to the memory of Erwin Baur, who died in December last. A short general account by Dr. Max Hartmann of his work and its significance in leading to a general appreciation of genetics in Germany is followed by a series of twelve articles written by colleagues of Baur whom he trained in the institute of which he was head, outlining in more detail the results achieved by the institute for plant breeding which he founded at Müncheberg. Five papers dealing with his theoretical work discuss respectively his investigations of mutation, linkage, specific crossing and self-sterility in Antirrhinum, and his genetical work on Pelargonium and Cleome. In seven other papers are considered the practical plant-breeding results obtained with rye, wheat, barley, sweet lupins, fodder plants, potatoes and grapes. Further papers on the practical results will appear in later numbers of the same journal. An obituary notice of Prof. Baur appeared in Nature of February 17.

\section{Barter in Great Britain}

IN the United States, the direct barter of goods and services has developed rapidly since 1931 as a practical method of alleviating unemployment and social distress. So far, little appears to have been done in Great Britain along similar lines, possibly because social insurance is highly developed, whereas in the United States it is practically non-existent. It is of interest therefore to note that, according to Progress and the Scientific Worker, experimental barter schemes have been inaugurated near Cheltenham and Petersfield. The Cheltenham scheme was started under the leadership of Prof. Scott of University College, Cardiff. Four acres of land were purchased 